\title{
The Rise of China and East Asia: A New Regional Order on the Horizon?
}

\author{
Jae Ho Chung ${ }^{1}$
}

Received: 11 October 2015/Accepted: 31 December 2015/Published online: 3 March 2016

(C) Fudan University and Springer Science+Business Media Singapore 2016

\begin{abstract}
This study assesses the impact of the China factor on the evolving international order in East Asia. In so doing, the article delves into the following four tasks: (1) identifying core questions worth asking about China's rise and the prospect of a power transition away from the US; (2) exploring key projections (both short- and log-term) about US-China relations as the foremost strategic variable in the 21st century; (3) examining amplifying dilemmas of East Asia as the prime stage for Sino-American hegemonic competition; and (4) reflecting on the highly uncertain future of the regional order in East Asia.
\end{abstract}

Keywords China's rise $\cdot$ US-China relations - East Asia $\cdot$ Regional order $\cdot$ Power transition

\section{Introduction}

Twenty-five years ago, many of us were hoping that the demise of the Cold War was to resolve all the agonizing problems that the world was then facing. It turned out that realities were neither that simple nor straightforward. The projected "end of history" never materialized, and post-Cold War complexities were such that sea changes associated with the implosion of the Soviet Union and the collapse of the socialist bloc have in turn generated new conflicts and reinvigorated old skirmishes. That is, the fading of ideological confrontation gave way to more traditional (ethnic, religious, territorial, history-related, and so on) and geo-strategic dilemmas around the globe, which had remained more or less dormant (or suppressed) during much of the Cold War era.

Jae Ho Chung

cjhir@snu.ac.kr

1 Department of International Relations, College of Social Sciences, Seoul National University, Seoul 151-742, Korea 
The biggest challenge, at this point and beyond, is indisputably the rise of China and the impact it is going to generate on the international political and economic structures. Back in the 15th century, when England's total wealth was barely onetenth of the Middle Kinsgdom (the Ming Dynasty), no one dared to predict that one day the West was to rise far above China. Even when the Qing Empire was plunged into the Opium War in the mid-19th century, her total wealth far surpassed that of the United States (hereafter the US) (Maddison 2007, 44).

Toward the end of the 19th century, a hegemonic shift was being shaped although much of it was fairly opaque at the time. America's "imperial under-stretch" created an intricate façade that the British Empire's global reach would last a bit longer than the actual wealth and might London possessed at the time. ${ }^{1}$ The outbreak of the First World War and the Great Depression that followed rendered London largely unable to sustain its hegemonic status, thereby paving the way for the first-ever power transition without a direct war between the hegemon and the hegemon-to-be.

In retrospect, America's hegemony was only partial in nature as the global strategic competition between Washington and Moscow led to an era of a divided or shared hegemony (aka. bigemony) for over half a century. When the Cold War finally ended with the disintegration of the Soviet Union in 1991, pundits around the world preached the arrival of Pax Americana without realizing that its "unipolar moment" was to expire much sooner than expected. The "rise (jueqi) of China," a premature discourse which had initially begun as a substitute for "Soviet threat", has soon become a reality to deal with and proven to be much faster than anyone's best guess. $^{2}$ As it stands now, no topics other than the China factor provide more food for thought concerning the future of international order in East Asia and beyond.

Is the center of gravity in global politics shifting towards Asia in tandem with the ascent of China? If so, will the new order be an Asian or Chinese one (Mahbubani 2009)? The center of gravity in international politics is probably shifting away from the West although the pace and magnitude of such a tectonic shift has yet to be gauged more precisely. For instance, Japan was the only Asian member in the Group of Eight (G-8), whereas five Asian nations (China, Japan, India, Indonesia, and South Korea) currently participate in the new framework of G-20. In the midst of global economic slowdown, some pundits even point to certain ominous signs analogous to the connections between World War I and the inter-war depression that prepared the soil for a gradual but then inconspicuous transition of power to the US How valid are such observations?

This article seeks to assess the impact of the China factor on the evolving international order in East Asia. In so doing, the study delves into the following four tasks: (1) identifying core questions worth asking about China's rise and the prospect of a power transition away from the US; (2) exploring key projections about US-China relations as the foremost strategic variable in the 21 st century; (3)

\footnotetext{
1 See Friedberg (1988), Ch. 7. The phrase "imperial under-stretch" is adapted from Zakaria (1998), Ch.3.

2 In 2003, projections were made for the timeline of 2030 when China would surpass Japan in total GDP at the earliest. China accomplished that goal in 2010, 20 years ahead of the projection. The report's prediction for China's catching up with the US was 2050 at the earliest but that could also come much earlier. See Goldman Sachs (2003), p. 1. Goldman Sachs revised these projections in 2009 but the new figures - the timeline of 2015 for Japan-also proved incorrect.
} 
examining dilemmas of East Asia as the prime stage for Sino-American hegemonic competition; and (4) reflecting on the uncertain future of East Asia.

\section{Identifying Key Questions for Consideration}

In efforts to mitigate the risks associated with forecasting the future international order in East Asia, it is both necessary and important to consider the following set of questions. First, how long can America successfully hold on to her hegemonic control so as to delay the arrival of a new alternative order (i.e., a post-American order)? Unlike the era of European dominance characterized by frequent, violent and transient power transitions, the process of a hegemonic shift away from the US could be much slower in pace and more complex in nature. That is to say, America's dominance has thus far been more total in nature than Europe's in the sense that Washington's hegemony was based on unrivaled control over the Americas and on its global reach. Therefore, the process of another power transition, if it should ever materialize, may perhaps be a much elongated one, replete with mutual suspicion (i. e., trust deficit) due to differing values, norms, and systems, constant contentions for rule-making rules, mutual learning and adaptation, confusion, and confrontation with intermittent cooperation. ${ }^{3}$

Second, what would the post-American order look like if it should ever materialize? In other words, can the US be creatively amalgamated into a new international order that consists of both the West and the "rest"? If the future international order should indeed be an Asian one, what sort of specific mix will it entail? A predominant view in the field posits that China tops the list as the most likely candidate to succeed America as the next hegemon. Since it is a cliché that economic wealth and military might are but the necessary conditions for the rise of a hegemon, the real question concerns if China can be sufficiently able and influential with her values, norms, standards and institutions that can confidently cure the ills of the modern (aka Western) world? ${ }^{4}$

Third, more fundamentally, is Asia a single entity or are there several geopolitical Asias? If the latter were the case-that is, if Asia denotes something more than Confucian-socialist China-projecting a simple linear transition of power in which an Asian order replaces the current American one is probably faulty and actual outcomes may perhaps be more complex and even messy. How the transition dynamics will play itself out in Northeast and Southeast Asia, as well as between continental and maritime Asia, are crucial points to watch. ${ }^{5}$

Fourth, perhaps most importantly, what does the future hold for China, none other than number one candidate for America's strategic competitor? Many Chinese analysts have long argued that China's internal/domestic problems are so diverse

\footnotetext{
${ }^{3}$ It should be borne in mind that, after Washington overtook London in GDP terms in 1872, it still needed 72 years before the actual power transition was materialized in 1944 with the establishment of the Bretton Woods system. See Chung (2015), p. 17.

${ }^{4}$ See the chapters by Kent and Kim in Chung (ed.), Assessing China's Power (2015).

5 Refer to the chapters by David Kang on Northeast Asia and Evelyn Goh on Southeast Asia in Chung (ed.), Assessing China's Power, Chs. 9 and 10. Also see Goh (2013).
} 
and serious that its ascendancy will invariably take a long time and Beijing is unlikely to cause troubles externally. Such assertions-often dubbed as "introversion" (neixianghua) discourses-do have some kernels of truth. At the same time, however, rebuttals may also be made of them. China is no Mexico. That is, China's domestic problems as such have been there for more than 30 years, but they did not seem to have deterred China from developing at a very fast pace up until now. Furthermore, comparatively speaking, a myriad of similar domestic troubles had not stopped the former Soviet Union from fiercely competing with Washington for hegemony for over five decades. ${ }^{6}$ In fact, there has been a tendency to exaggerate China's domestic problems and their impact on its growth potentials.

Bonaparte Napoleon once said, "[W]hen China woke from its slumbers, it would astonish the world". It appears that is precisely what is happening now. The world is totally amazed at the swift ascent of China across the board, not only economically but also culturally and even militarily (Subramanian 2011; Jacques 2012; White 2012; Cardenal and Araujo 2013; Wortzel 2013; Dyer 2014). In 2010, the world was shocked to hear that China's economic power had just surpassed that of Japan (only in terms of GDP, though). It did not stop there as the surprises continued with the successful test flight of a J-20 stealth fighter and the launch of Chinese space station Tiangong in 2011, and the establishment of China-initiated Asian Infrastructure Investment Bank (with 57 nations as its founding members) in 2015.

There is no doubt that Chinese, too, are as much astonished by their own remarkable successes. As a matter of fact, the Chinese-elite, ordinary people and bureaucracies alike- have been going through a search for their own identity in the midst of a rise that has been perhaps too fast and far-reaching. ${ }^{7}$ While it is true to a certain extent that China has been undergoing a process of strategic soul-searching, it is equally possible that Beijing's traditional Sino-centric view of tianxia (天下) may not be completely replaced by the modern conception of shijie (世界). ${ }^{8}$ On one hand, we have seen an increasing level of integration between China and the world, pointing to a possibly successful amalgamation of the former into the latter. On the other hand, however, China's practices of peripheral control (and resultant maritime disputes in recent years), Beijing's novel system of "partnerships" (huoban guanxi) apparently as a substitute for military alliances, and of often revisionist interpretations of history (as a basis of her assertive territorial claims) suggest that China may be China that is perhaps China (Li 2010; Bowring 2012). Then, which of the two images is going to better capture the future China?

\footnotetext{
${ }^{6}$ For an assessment that, despite various domestic troubles, China is likely to rise and seek more power. See Chung (2006). Also see Whyte (2010).

${ }^{7}$ A series of puzzling events in 2010 regarding China's external behavior is a good example of this type of observations. See Wang (2011). Also for a wide range of Chinese self-perceptions, see Guoji guanxi yanjiu (Studies of International Relations), No. 1 (2013), pp. 5-53; and Suisheng Zhao, "China's Power from a Chinese Perspective (I): A Developing Country versus a Great Power" and Zhimin Chen, "China's Power from a Chinese Perspective (II): Back to the Center Stage," in Chung (ed.), Assessing China's Power, pp. 251-289.

${ }^{8}$ Tianxia is a sort of hierarchical order in which China is placed at the apex and other nations are categorized into different ranks in accordance with the standards set by the Middle Kingdom. On the other hand, shijie is a horizontal/reciprocal/equal order among sovereign nations, quite similar to the ideas embedded in modern international law. See Zhao (2005) and Zhou (2011).
} 


\section{US-China Relations: Quo Vadis?}

US-China relations undoubtedly constitute a key to understanding the evolving international and regional order of the 21 st century. The global economic crisis ignited by the Lehman Brothers bankruptcy forcefully revealed the long-overlooked sources of trouble in the American economy and the US-led system of international financial and monetary management. ${ }^{9}$ If the US can still sustain her economic competitiveness and military preeminence after the global economic crisis, then, the heated debate on America's future relations with China and their strategic ramifications for Asia are bound to continue. Given that popular perceptions of China's rise have generally gone far ahead of her actual capabilities (i.e., China's comprehensive national power has been overestimated and often exaggerated), the perceived power gap between Washington and Beijing may be as much important as the actual power gap between the two giants. ${ }^{10}$

By and large, five schools of thought are available on the future of US-China relations. The first contends that China's rise, even in the long run, will not suffice to replace America in Asia or elsewhere for that matter (Segal 1999; Sutter 2005; Beckley 2011). This school of thought, often dubbed as "the middle (-level) Kingdom" school or the "Muddling China" school, does not view the ascent of China as having such colossal impact of fundamentally altering the status quo or possibly substituting for the global role hitherto performed by the US. In contrast, proponents of this school tend to underscore a wide array of domestic problems that China is facing (Beardson 2013; Gurtov 2013; Fenby 2014; Abrami et al. 2014). While this particular view commanded huge audience until the mid-2000s, given the fast-narrowing power gap with America, not to speak of surpassing Japan in GDP terms in 2010, it appears to be losing its ground.

The second school of thought suggests that China's mode of diplomacy has been far more subtle and sophisticated than usually assumed, thereby seeking hard to avoid direct and explicit confrontation with America by all means. ${ }^{11}$ Its proponents focus on China's intentions as to whether Beijing is determined to alter the status quo and related norms and institutions after its rise becomes more visible. Many proponents of this school are of the view that China's intentions have yet to be fixed and, therefore, the international community needs to engage more fully with China in order to guide her into a responsible member that honors and respects the status quo. ${ }^{12}$ Once China's intentions should prove to be revisionist, however, this school holds that Sino-American confrontation may become inevitable.

The third school contends that China's rise forewarns the inevitability of SinoAmerican confrontation and conflict, probably first in East Asia as the prime stage

\footnotetext{
${ }^{9}$ See, for instance, Financial Times (December 4, 2008).

${ }^{10}$ In 2014, 10 percent of Americans thought that China's power has already surpassed that of the US. See the survey outcomes by Pew Global Research at http://www.pewglobal.org/database/indicator/33/ country/45.

${ }^{11}$ Many-most notably, Avery Goldstein, David Lampton, Kenneth Lieberthal, Evan Medeiros, and David Shambaugh - are key proponents of this school of thought.

${ }^{12}$ Many belonging to the so-called engagement school hold this view. See, for instance, Kissinger (2012).
} 
for US-China strategic competition. Its proponents subscribe to a structuralist view in that the ascent of China, regardless of her ideas and intentions, is bound to constrict the room for strategic maneuvering by America, thereby precipitating a "clash of Titans" (Betts 1993; Mearsheimer 2001; Friedberg 2011; Zhou 2012; Yan 2013). Compared with other perspectives, this view is particularly more pessimistic and even apocalyptic in nature and is generally in favor of containing China as a policy prescription. In what specific form this clash will actually take place between the two titans in the era of nuclear deterrence remains unspecified, however.

The fourth school projects that China's rise may lead to a peaceful power transition (like the one between UK and the US in the first half of the 20th century) although uncertainties may loom large in the long haul. That is to say, ample room is available for mutual learning and adaptation between China on one hand and the US on the other. According to this relatively optimistic view, future Sino-American relations may resemble that of US-Soviet relations in the sense that a certain mode of shared/divided hegemony (aka. bigemony) may gradually come into being and get institutionalized over time. ${ }^{13} \mathrm{~A}$ crucial question remains to be answered, however: when China's comprehensive national power should surpass America's in due time, will it be possible for Beijing's Sinocentric DNA to be fully reconciled with Washington's unilateralist gene? ${ }^{14}$

The fifth school of thought maintains the position that East Asia, the region so uniquely accustomed to the traditional Sino-centric order, is unlikely to join the US one-sidedly simply to balance against the rise of China. Its proponents take note of an "anomaly" that, unlike Europe, few nations in Asia appear to have fears of China and therefore have sought to balance against the rising China (Buzan 2004; Ross 2006; Kang 2007; Kang 2013). The lack of explicit balancing against China in East Asia was not because there was no fear as such in the region but rather because regional states did not find a convenient or effective way with which to express its genuine fear of China while at the same time maximizing engagement with Beijing. Recent evidence suggests, however, that post-2010 East Asia has been gradually preparing for some worst-case scenarios vis-à-vis the rise of an assertive China, particularly by way of consolidating security ties with the US as an offshore balancer.

\section{Sino-American Strategic Competition and Asia's Growing Concern}

As far as Asia is concerned, US-China confrontation is no longer a theoretical ploy. With America's "return to Asia", "pivot to Asia", or "rebalancing", East Asia has become the principal stage for Sino-American strategic competition. In retrospect, European dominance was much less total in nature (i.e., no single European power was able to control the whole of Europe) and the European powers' rise was as

\footnotetext{
${ }^{13}$ While the US-USSR bigemony was largely based on ideological divide, the anchor for the US-China bigemony remains unspecified.

${ }^{14}$ Civilizational identities and/or political regime types could work as key variables in this regard. See, for instance, Katzenstein (2012) and Kliman (2015).
} 
much due to the passing weakness of other nations as it was due to their own strength (Chua 2007). In contrast, the US's dominance in the Americas has thus far been much more total than Europe's, and that is precisely what China is seeking to achieve at least in the region of Asia before moving beyond (Kaplan, 2014, Ch. 2). Hence, Asia-East Asia in particular - is bound to be the prime stage for strategic competition between the two titans.

In spite of Washington's contention that America's rebalancing is not solely about containing China, it is much about China in every sense of it. ${ }^{15}$ With America's rebalancing and China's countering measures, a spiral stage is being set for strategic competition in East Asia on a wide range of sectors and domainspolitical, diplomatic, economic, military, and normative.

Politically and diplomatically, in response to growing concerns with the rise of an "assertive" China within the region, Washington chose to rebalance by deploying marines in Darwin, Australia, sending littoral combat ships to Singapore, and by deepening defense cooperation with Japan, South Korea, Thailand, the Philippines, New Zealand, Indonesia and Vietnam, as well as announcing new plans to redistribute naval capabilities by 2020 in favor of the Pacific at the expense of the Atlantic. ${ }^{16}$ China has also been responding with its "peaceful rise" tenet as if Asia has no need for an American pivot. Naturally, the US and China are fiercely competing with each other by way of consolidating their respective alliances and extending partnerships.

Economically, Sino-American competitions are being increasingly structurized between the US-led Trans-Pacific Partnership (TPP) and China-centered FTA networks (i.e., RCEP) and Free Trade Area of the Asia Pacific (FTA-AP). These competing regional economic networks are partly exclusive in that the former leaves China out and the latter presupposes the absence of the US. While the possibility of fusion of some sort between the two cannot be totally precluded, as it stands now, the securitization of economic cooperation appears more likely.

In military terms, too, a spiral mode of competition is apparent. In direct efforts to cope with China's anti-access/area-denial (A2AD) strategy anchored on anti-ship ballistic missiles, anti-satellite warfare, and cyber warfare, the US has been investing heavily in the concept and system of AirSea Battle. Such spiral competition between counter-intervention and counter-counter intervention will only intensify, locking the two giants more closely in for a conflict.

In terms of norms and values, the competition between the Washington Consensus and the Beijing Consensus goes unabated. As China's soft-power offensive is no longer merely reactive-i.e., countering America's positions-but increasingly proactive and innovative, the scope of its challenge has also expanded from such conventional realms as human rights, developmental models, and democracy to those of internet governance, climate change, clean energy, and

\footnotetext{
15 For useful readings on the theme, see Green (2013) and McDevitt (2012).

16 See Resnick (2013) and "The US Navy Wants to Show China Who's Boss," Foreign Policy, December 14, 2015 at http://foreignpolicy.com/2015/12/14/the-u-s-navy-wants-to-show-china-whos-boss/?utm_ source=Sailthru\&utm_medium=email\&utm_campaign=New\%20Campaign\&utm_term=\%2ASituation\% 20Report.
} 
"Asian security by Asian people". ${ }^{17}$ If the prevailing projections that China is likely to surpass the US by 2025 in economic terms and to achieve military parity by 2035 are correct, this norms/values competition is likely to weigh in heavily thereafter.

Of course, US-China relations are not simply anchored only on conflictual dynamics; they are also based on close cooperation, though selectively. If the past and recent records are any practical guide, Washington and Beijing are more likely and willing to cooperate with each other on issues that are geographically farther away from Asia and less related in nature to hard-security ones. Hence, East Asia, constituting both America's vital interest and China's core interest, is invariably a key region of contention between the two titans.

How has East Asia been thus far responding to the rise of China and related strategic dynamics? Engagement (i.e., maintaining good relations, including close economic linkages, with China) has been a common denominator for all East Asian nations, as it would be unwise not to expand contacts with an economically rising China. That does not necessarily mean that they lack the fear of China, however. As a matter of fact, it may not be the lack of fear per se but rather the absence of explicit display of such fear. While a few nations (most notably North Korea and Cambodia) have been bandwagoning with China, changes are on the way even with these nations, most notably Myanmar. "Balancers" (i.e., those that do not welcome the rise of China and instead are highly concerned about it) like Japan, India and Australia have stepped up their act of checking on China, particularly since 2010. A predominant majority of East Asian nations, however, has opted for hedging - i.e., seeking to maintain good relations with both Washington and Beijing, thereby maximizing economic gains from China and, at the same time, sustaining security protection from the US just in case of the emergence of an assertive/aggressive China (Chung 2009; Brown 2011; Sutter et al., 2013).

Beijing's rhetoric and action since 2010 has been particularly alarming to many East Asian nations. The fusses about China's branding of South China Sea as newly defined "core interests" (hexin liyi), Beijing's frequent skirmishes with Tokyo over the Senkaku/Diaoyu, China's one-sided tilt toward North Korea on the Cheon'an sinking and the Yonpyong shelling, Beijing's loud voice against joint military drills by the US and South Korea in the Yellow Sea, China's use of rare earth elements as a means for sanction against Japan, Beijing's growing maritime disputes with Manila and Hanoi, and so on created huge stirs in the international community. Not surprisingly, intense debates were waged over whether China's external strategy was being transformed from one of "biding time" (taoguang yanghui) to that of "flexing muscles" (yousuo zuowei). ${ }^{18}$

In spite of Beijing's visible efforts for damage control since late 2010, by the government and policy experts alike, concerns and worries have amplified from

\footnotetext{
17 "Asian security by Asian people" is a principle proposed by China at the Conference on Interaction and Confidence-Building in Asia (CICA) held in Shanghai in 2014.

18 Even among Chinese experts, a similar debate is being waged. Compare, for instance, the remarks by Wu Jianmin (who stresses the need to go back to Deng Xiaoping's dictum of taoguang yanghui) and Cui Liru (who calls for a change toward a more proactive diplomacy). See Guoji guanxi yanjiu (Studies of International Relations), No. 1 (2013), 10-11, 14. Also compare Johnston (2013) with Zha Jihong (2011).
} 
Australia, Vietnam, and India to Japan and Mongolia. ${ }^{19}$ Such worries are particularly prominent in the countries that share borders with China. Three factors account for this geopolitical sensitivity. First, distance really matters. Since the security dilemma is bound to be more intense for countries that border on each other, smaller neighbors are naturally more wary of China's "assertive" behavior in tandem with its rise. Second, available records forcefully demonstrate that the People's Republic's projection of military might was far more proactive toward her immediate neighbors than toward distant or extra-regional states (Ryan et al. 2003, 18-19). Given that, in spite of Beijing's pronounced rhetoric of "friendly neighbor policy" (mulin youhao zhengce), concerns and worries have lingered among her neighbors. ${ }^{20}$ Third, deep-seated memories of Chinese dominance in Asia in the last two millennia and, more importantly, the newly-brewing historical controversies between China and some regional states have added fuel to the generic concern about the rise of a strong China.

What can East Asia do independently to find a way out of this complicated labyrinth closely intertwined with the dynamics of great-power competition? Considering the huge differences between Northeast and Southeast Asia, as well as considerable intra-regional variations, even among the member states of the ASEAN, a well-coordinated regional approach to China is highly unlikely. ${ }^{21}$ Therefore, one principal variable here is the US. It appears that it is high time Washington must now look into herself and face the problems head on. It must seek hard to solve the crucial problems of global imbalances and domestic troubles by putting her economic act together, instead of passing all the bucks to other nations and "demonizing" her competitors. ${ }^{22}$ This is one very important-if not the onlyway for the US to prevent her global leadership (real and perceptual alike) from slipping away or at least to slow down such a process which is probably already underway.

The core strategic dilemma of the East Asian region and China's immediate neighbors in particular has tended to manifest itself mainly in the form of strategic hedging between Washington and Beijing. Within such contexts, America has found ample room for rebalancing just in case China should become a threat to the region as a whole. Beijing, too, has been deploying its own tactics of assuaging the fears of Asian neighbors to counter America's rebalancing efforts. In the midst of all these courting and counter-courting, one thing has become clear: whichever of the two titans that first preaches the "with us or against us" exclusivity is likely to lose more than gain since it will ipso facto constitute a greater threat to East Asia which is already too much agonized over how to position itself between Washington and Beijing. ${ }^{23}$

\footnotetext{
19 Of course, it remains to be seen whether the grandiose geo-economic scheme of "One Belt, One Road" will be able to mitigate such concerns on the part of the regional states.

20 Some even sarcastically dub Beijing's friendly neighbor policy as a "buffer strategy".

21 Emmerson writes: "If Sino-American rivalry escalates, ASEAN members could split into Chinadeferring and China-defying camps, ruining the group's ability to lead." See Emmerson (2012). For a similar view, see Goh in Chung (2015), pp. 222-223.

22 This is also a recommendation put forward by Friedberg (2011), Ch. 11.

23 Chung (2009).
} 


\section{Uncertain Passage, Uncertain Future}

If there is a single word that best encapsulates the strategic landscape of East Asia today, it would be uncertainty. If the current trend of China's ascent (and fastnarrowing power gaps with the US) should continue, the crucial variable undoubtedly rests on whether China would continue to stick with her principles and tenets of external strategy even after she has achieved undisputed primacy in international politics and economics. Some suggest that it may perhaps become unavoidable down the road that China's ever-heightened international status will make it increasingly difficult for the regional states to deal with Beijing on an equal footing, the long-standing rhetoric of the 'five principles' notwithstanding. The wealthier and the more powerful China becomes, the larger the perceptual disparity between China and her regional neighbors may get. If China's modus operandi were to change from that of "status-quo maintenance" (weiwen) to that of "active management" (jingying) of world affairs, will China then still continue to be a "modest giant," consciously refraining from being showy and imposing on her neighbors? ${ }^{24}$

On a more behavioral level, will China continue to hold on to the well-known power-projection principle of "no messing around if not messed with first" (ren bu fan wo wo bu fan ren)? This highly reserved and "reactive" (houfa zhiren) principle has long been a key characteristic of China's military and external strategy. Once China sits at the top of the international order, economically and militarily, will the operational definition of fan remain unchanged? Will the level of China's tolerance toward others also remain the same as before? (Chung 2013, 46-48). Why did China delete the phrase of "not assuming leadership" from its well-received twin concept of bu dangtou bu chengba? Why has China come up with a new concept of "active defense" (jiji fangyu) in its 2014 edition of the National Defense White Paper? These are some key questions that East Asian nations will have to chew on in the years to come.

Power relations in East Asia are evolving rapidly to the extent that pundits are out of their breath to catch up with key events happening here and there all over the region. It appears that China's external relations may perhaps have entered its "third cycle," with the first cycle being 1949-1978 (an era of "survival") and the second being 1979-2009 (an era of "development"). What the third cycle of China's external relations is to signify remains largely veiled at this point. One thing is clear: China no longer just bides her time. China is proactive, initiating and even innovative, outwitting the US in certain regards. ${ }^{25}$

Can China do something for the sake of East Asia and the international community? Will there be a moment—or a turning point per se-when China's official stance on many norm-related issues may fundamentally shift so as to resolve key problems once and for all? Given that China's power and influence continue to

\footnotetext{
24 Such concern was raised in Chung (2011), pp. 175-190.

25 China has recently been emphasizing the principle of "proactively initiating" (zhudong jinqu) and seeking to make China into a "major playfield of global diplomacy" (zhuchang waijiao). Such initiatives as "One Belt, One Road," the Asian Infrastructure Investment Bank, the New Development Bank, and so on are good examples in point.
} 
grow, will Beijing's recognition of internationally accepted norms and values also increase accordingly? Considering that Beijing has continuously emphasized the need to restructure and "democratize" the international system, is China willing and ready to sacrifice her own interests in favor of international public goods? ${ }^{26}$

It is suggested that a wide range of global and regional problems that the world is currently facing can hardly be resolved without active cooperation between Washington and Beijing. Granted that US-China cooperation is but a necessary condition for coping with some of the key global problems, though important ones, we still need the rest's active support, implementation, and contributions-the sufficient condition-for managing urgent problems both effectively and persuasively. Without active participation of the rest, the future is more likely to become a distorted bigemony again, a scenario that the international community may not necessarily prefer to have in the long run. The least the US and China can do for the world is to take precautions so as to reduce the risk of "little things" that could ignite big conflicts (as they did in 1914) (Rosecrance 2015, 212-218).

To flip the question, what will the US be doing in the meantime? The precedent of a peaceful power transition between the United Kingdom and the US forcefully demonstrates to us that a self-complacent power is bound to fade. In a nutshell, the vector of three factors-what Washington will do to preserve a favorable balance of power, how fast and stable Beijing's rise will be, and how the two titans will be perceived by the region-holds the key to delineating the future that is much too uncertain.

Acknowledgments The research was supported by Asia Research Infra-Grant of Seoul National University's Asia Center (\#0448A-20150016).

\section{References}

Abrami, Regina, William Kirby, and F. Warren McFarlan. 2014. Can China Lead? Reaching the limits of power and growth. Cambridge: Harvard Business Review Press.

Beardson, Timothy, and Stumbling Giant. 2013. The threats to China's future. New Haven: Yale University Press.

Beckley, Michael. 2011. China's Century? Why America's Edge Will Endure. International Security 36 (3): 46-78.

Betts, Richard. 1993. Wealth, power and instability: East Asia and the United States after the Cold War. International Security 18(3): 34-77.

Bowring, Philip. 2012. China's selective reading of history weakens its South China sea claims. South China Morning Post.

Brown, Jessica. 2011. Southeast Asia’s American Embrace. Foreign Policy Analysis 7 (March 29, 2011). Buzan, Barry. 2004. How and to whom does China matter? In Does China matter? A reassessment, ed, Barry Buzan and Rosemary Foot, Ch. 10. London: Routledge.

China Lectures US on Economy. 2008. Financial times, December 4.

Chua, Amy. 2007. Day of empire-how hyperpowers rise to global dominance-and why they fall. New York: Doubleday.

Chung, Jae Ho 2006. Charting China's Future. Lanham: Rowman \& Littlefield.

Chung, Jae Ho. 2009. East Asia responds to the rise of China: Patterns and variations. Pacific Affairs 84 (4): $657-675$.

\footnotetext{
${ }^{26}$ From the 16th (2002) to 18th (2012) Party Congresses, "reforming or democratizing the international order deemed unjust and unreasonable" (guojiguanxi minzhuhua) was officially stressed.
} 
Chung, Jae Ho. 2011. Decoding the Evolutionary Path of Chinese Foreign Policy, 1949-2009: Assessments and Inferences. East Asia 28(3): 175-190.

Chung, Jae Ho. 2013. Zhongguo yizhi you yizhong shoukunxintai-yiwei hanguo xuezhe de guandian (China always holds on to a sort of siege mentality: A view of a Korean Scholar, 46-48. Renmin luntan (People's Forum), April 2013.

Chung, Jae Ho. 2015. Assessing China's Power, In Assessing China's Power, ed. Jae Ho Chung. New York: Palgrave.

Dyer, Geoff. 2014. The Contest of the Century: The New Era of competition with China-and how American can win. New York: Vintage.

Emmerson, Donald. 2012. Challenging ASEAN: The US Pivot through Southeast Asia's eyes. Global Asia 7(4): 25.

Fenby, Jonathan. 2014. Will China dominate the 21st Century?. Cambridge: Polity Press.

Friedberg, Aaron L. 1988. The Weary Titan: Britain and the experience of relative decline, 1895-1905. Princeton: Princeton University Press.

Friedberg, Aaron L. 2011. A contest for supremacy: China, America, and the struggle for mastery in Asia. New York: Norton.

Goh, Evelyn. 2013. The struggle for order: Hegemony, hierarchy and transition in post-cold War East Asia. Oxford: Oxford University Press.

Goh. 2015. China's power in the regional context (II): Southeast Asia. In Assessing China's power, ed. Chung, Ch. 10.

Goldman, Sachs. 2003. Dreaming with the BRICS: The path to 2050.

Green, Michael. 2013. Whither the Pivot in 2013? CSIS-Asia Policy Blog.

Gurtov, Mel. 2013. Will This Be China's Century? A Skeptic's View. Lynne Rienner: Boulder, CO.

Jacques, Martin. 2012. When China rules the world: The End of the western world and the birth of a new global order. London: Penguin.

Johnston, Alastair Iain. 2013. How new and assertive is China's new assertiveness? International Security 37(4): 7-48.

Juan Pablo, Cardenal, and Heriberto, Araujo. 2013. China's silent army: The pioneers, traders, fixers and workers who are remaking the world in Beijing's image. New York: Crown.

Kang, David C. 2007. China rising: Peace, power, and order in East Asia, Ch.1. New York: Columbia Univeristy Press.

Kang, David. 2013. Why is not the Rest of Asia Afraid of China? Foreign Policy, April 25, 2013. http:// www.foreignpolicy.com/articles/2013/04/25/paper_tiger_china_military_buildup.

Kaplan, Robert. 2014. Asia's Cauldron: The South China Sea and the end of a stable Pacific, Ch. 2. New York: Random House.

Katzenstein, Peter (ed.). 2012. Anglo-America and its discontents: Civilizational identities beyond west and east. London: Routledge.

Kent, Ann, Hankwon Kim. 2015. In Assessing China's Power; and Rosemary Foot and Andrew Walter, China, the United States, and Global Order, ed. Jae Ho Chung. Cambridge: Cambridge University Press.

Kissinger, Henry. 2012. The future of US-China relations: Conflict is a choice, not a necessity. Foreign Affairs 91(2): 44-55.

Kliman, Daniel M. 2015. Fateful transitions: How democracies manage rising powers. Philadelphia: University of Pennsylvania Press.

Li, Hongmei (editor of PD). 2010. Uncle Sam too senile to Lead Asia. People's Daily.

Maddison, Angus. 2007. Chinese economic performance in the long run, 960-2030, vol. 44, 2nd ed. Paris: OECD. (revised and updated).

Mahbubani, Kishore. 2009. The new Asian hemisphere: The irresistible shift of global power to the east. New York: PublicAffairs.

McDevitt, Michael. 2012. America's new security strategy and its military dimension. Global Asia 7(4): 14-17.

Mearsheimer, John. 2001. The tragedy of great power politics, Ch. 10. New York: W. W. Norton.

Resnick, Evan. 2013. The perils of containing China. RSIS Commentaries 69.

Rosecrance, Richard N. 2015. Contingency as a cause (or little things mean a lot). In The next great war? The roots of world war I and the risk of US-China conflict, ed. Richard N. Rosecrance, and Steven Miller, 211-218. Cambridge: MIT Press.

Ross, Robert S. 2006. Balance of power politics and the rise of China: Accommodation and balancing in East Asia. Security Studies 15(3): 392-395. 
Ryan, Mark A, David M. Finkelstein and Michael A. McDevitt. 2003. Chinese Warfighting. New York: M. E. Sharpe.

Segal, Gerald. 1999. Does China matter? Foreign Affairs 78(4): 24-36.

Subramanian, Arvind. 2011. Eclipse: Living in the shadow of China's economic dominance. Washington, DC: Peterson Institute for International Economics.

Sutter, Robert. 2005. China's rise in Asia: Promises and perils. Lanham: Rowman \& Littlefield.

Sutter, Robert, Michael Brown, Timothy Adamson, Mike Mochizuki and Deepa Ollapally. 2013. Balancing acts: The US rebalance and Asia-Pacific stability. Washington, D.C.: The Sigur Center for Asian Studies.

Wang, Jisi. 2011. China's search for a grand strategy. Foreign Affairs 90(2).

White, Hugh. 2012. The China choice: Why we should share power. Oxford: Oxford University Press.

Whyte, Martin K. 2010. Myth of the Social Volcano: Perceptions of Inequality and Distributive Justice in Contemporary China. Stanford: Stanford University Press.

Wortzel, Larry. 2013. The dragon extends its reach: Chinese military power goes global. Washington, DC: Potomac.

Yan, Xuetong. 2013. Lishi de guanxing (The Inertia of History). Zhongguo chubanshe: Beijing.

Zakaria, Fareed. 1998. From wealth to power: The unusual origin of America's world role. Princeton: Princeton University Press.

Zha, Jihong (ed.). 2011. Daguo jueqi xuyao daguo xintai (The rise to a great-power status requires a great-power mindset). Beijing: Sanxia chubanshe.

Zhao, Tingyang. 2005. Tianxia tixi-shijie zhidu zhexue daolun (The Tianxia system-a philosophical guide to international institutions). Jiangsu jiaoyu chubanshe: Nanjing.

Zhou, Fangyin. 2011. Chaogong tixi de junheng fenxi" (A balanced analysis of the tributary system). In Zhongguo jueqi yu shijie zhixu (China's Rise and the International Order), ed. Chen Qi. Beijing: Shehuikexue chubanshe.

Zhou, Tianyong. 2012. Zhongmei guojia liyi chongtu de kenengxing fenxi" (An Analysis of the Possible Conflict of Interests between China and the US), Lilun dongtai (Theoretical Trends), No. 1936, 1318.

Jae Ho Chung is a professor of international relations and the director of the Program on US-China Relations (SNU-AC) at Seoul National University, Korea. Professor Chung is the author or editor of seventeen books, including Central Control and Local Discretion in China (Oxford University Press 2000), Between Ally and Partner (Columbia University Press 2007), Assessing China's Power (Palgrave 2015), and Centrifugal Empire (Columbia University Press 2016), in addition to over seventy journal articles and book chapters (including six in China Quarterly). He is the recipient of Seoul National University's Best Researcher Award in 2009 and of the Korean Association for International Studies' Best Book Award in 2012. 